\title{
Assessing the tsunami mitigation effectiveness of the planned Banda Aceh Outer Ring Road (BORR), Indonesia
}

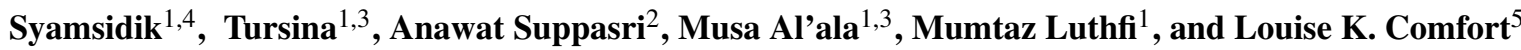 \\ ${ }^{1}$ Tsunami and Disaster Mitigation Research Center (TDMRC), Syiah Kuala University, \\ Gampong Pie, Banda Aceh 23233, Indonesia \\ ${ }^{2}$ International Research Institute of Disaster Science (IRIDeS), Tohoku University, \\ Aramaki Aza-Aoba 468-1, Aoba-ku, Sendai 980-0845, Japan \\ ${ }^{3}$ Civil Engineering Department, Syiah Kuala University, J1. Syeh Abdurrauf No. 7, \\ Banda Aceh 23111, Indonesia \\ ${ }^{4}$ Civil Engineering Department, Faculty of Engineering, Syiah Kuala University, \\ J1. Syeh Abdurrauf No. 7, Banda Aceh 23111, Indonesia \\ ${ }^{5}$ Graduate School of Public International Affairs, University of Pittsburgh, Pittsburgh, USA
}

Correspondence: Syamsidik (syamsidik@tdmrc.org, syamsidik@unsyiah.ac.id)

Received: 24 September 2018 - Discussion started: 23 October 2018

Revised: 5 January 2019 - Accepted: 7 January 2019 - Published: 31 January 2019

\begin{abstract}
This research aimed to assess the tsunami flow velocity and height reduction produced by a planned elevated road parallel to the coast of Banda Aceh, called the Banda Aceh Outer Ring Road (BORR). The road will transect several lagoons, settlements, and bare land around the coast of Banda Aceh. Beside its main function to reduce traffic congestion in the city, the BORR is also proposed to reduce the impacts of future tsunamis. The Cornell Multi-grid Coupled Tsunami Model (COMCOT) was used to simulate eight scenarios of the tsunami. One of them was based on the 2004 Indian Ocean tsunami. Two magnitudes of earthquake were used, that is, 8.5 and $9.15 M_{\mathrm{w}}$. Both the earthquakes were generated from the same source location as in the 2004 case, around the Andaman Sea. Land use data of the innermost layer of the simulation area were adopted based on the 2004 condition and the land use planning of the city for 2029. The results of this study reveal that the tsunami inundation area can be reduced by about $9 \%$ by using the elevated road for the earthquake of magnitude $9.15 M_{\mathrm{w}}$ and about $22 \%$ for the earthquake of magnitude $8.5 M_{\mathrm{w}}$. Combined with the land use planning 2029, the elevated road could reduce the maximum flow velocities behind the road by about $72 \%$. Notably, the proposed land use for 2029 will not be sufficient to deliver any effects on the tsunami mitigation without the elevated road structures. We recommend the city to construct
\end{abstract}

the elevated road as this could be part of the co-benefit structures for tsunami mitigation. The proposed BORR appears to deliver a significant reduction of impacts of the smaller intensity tsunamis compared to the 2004 Indian Ocean tsunami.

\section{Introduction}

Tsunami mitigation by means of structural measures is not always affordable in the case of developing countries. In contrast, the threats posed by tsunamis are real and have the potential to deliver severe impacts on the coastal area and the community at risk. Banda Aceh is one of the most severely affected cities due to the 2004 Indian Ocean tsunami; however, it is difficult to follow the guidelines demonstrated by advanced countries that develop massive physical structures to mitigate the future impacts of tsunamis. This is still beyond the financial capacity of the city. In contrast, based on the probabilistic tsunami hazard assessment, this area could potentially be affected by a tsunami larger than $0.5 \mathrm{~m}$, that is, about $10 \%$ higher, annually (Horspool et al., 2014). Therefore, seeking alternative and economic ways to mitigate the impacts of tsunamis could help the city in creating a more resilient region. Modifying the morphology and land use of the coastal front of the area can reduce the tsunami wave energy 
(Ohta et al., 2013). The nonlinearity effects generated on the inland tsunami wave run-up are closely related to the local topography of the area (Mori et al., 2017). The key parameters of reducing damages due to tsunami waves are decreasing the wave velocity and the inundation depths (Kreibich et al., 2009; Yamamoto et al., 2006). These are better represented by a quadratic Froude number $\left(\mathrm{Fr}^{2}\right)$ (Ozer and Yalciner, 2011). Constructing a high seawall is costly. In the case of Banda Aceh, the estimated maximum tsunami height based on the 2004 Indian Ocean tsunami was $15 \mathrm{~m}$ (Lavigne et al., 2009). Only the sea walls higher than $5 \mathrm{~m}$ could contribute to reducing the destructive effects of tsunamis as in the case of the 2011 Tohoku tsunami (Nateghi et al., 2016). The cost of the structure is unarguably expensive. Furthermore, the tsunami wave has long-wave characteristics, whereby blocking the wave will only indicate the delayed time of the wave to reach a certain area behind the seawall due to the scouring process (Chen et al., 2016). Inequalities of the hydrostatic forces generated around the seawalls and the process of overflowing will occur and destroy the structures (Ozer et al., 2015); however, this could reduce the tsunami wave energy (Guler et al., 2018).

Another way to reduce the tsunami wave energy is by using an elevated road. The elevated road can function as an inland tsunami defense structure that could stop the tsunami wave or reduce its intensity as revealed in the case of the 2011 Great East Japan Earthquake and Tsunami (GEJET; Goto et al., 2012a). In the GEJET case, the Tobu highway in Sendai was the maximum limit of the tsunami inundation area in Sendai of Miyagi Prefecture in Japan (Abe et al., 2012; Goto et al., 2012b; Sugawara et al., 2012). A new $6 \mathrm{~m}$ elevated road is now being constructed in Sendai, the idea of which was adapted from the tsunami mitigation effects revealed by the Tobu highway structure during the 2011 Tohoku tsunami (Suppasri et al., 2016). Japan is an exemplary nation that promotes a tsunami multilayered defense system, either by structural or nonstructural mitigation. A tsunami multi-defense system is a set of structures to mitigate the impacts of tsunamis. The concept was introduced in the Tohoku region of Japan during the rehabilitation and reconstruction process following the 2011 tsunami. The structures consist of sea walls, coastal forests, a canal that is parallel to the coastline, escape hills, and elevated roads. Concerning structural mitigation, the GEJET-affected areas have been developing several massive structures to prevent future tsunami losses (Strusinska-Correira, 2017; Koshimura et al., 2014; Pakoksung et al., 2018).

As a result of its population and economic growth, Banda Aceh is planning to construct a road transect as a response to the traffic demands of the city. One of the most recently introduced plans is a road that will circle the city from its periphery. The proposed road is named the Banda Aceh Outer Ring Road (BORR). Initially, the road was only introduced by a road transect and the detailed structure of the road is yet to be decided. This is part of a long-term development program as stipulated in its spatial planning that aims to regulate the city planning until 2029 (Government of Banda Aceh, 2009). In the spatial planning, no new significant tsunami mitigation infrastructure has been included. The structural mitigation facilities that were developed between 2005 and 2010 include four escape buildings, one tsunami museum that also functioned as a tsunami escape building, and several escape routes. A $7 \mathrm{~km}$ revetment structure was constructed between 2006 and 2010 to reshape the city's coastline and to prevent further coastal erosion problems (Syamsidik et al., 2015).

To address the gap as stated earlier, this research aimed to investigate the reduction of potential tsunami destructive impacts through an elevated road structure parallel to the coastline of Banda Aceh (BORR). The Cornell Multi-grid Coupled Tsunami Model (COMCOT), a two-dimensional horizontal model, was utilized to numerically simulate the tsunami characteristics as well as to evaluate the reduction impacts of BORR. Two types of land use maps in 2004 and 2029 were used to evaluate the mitigation effect of future tsunamis. The evaluation of the performance of the elevated road to reduce the tsunami wave energy may contribute to a better city planning of Banda Aceh in a long-term development program.

\section{The study area}

Banda Aceh is situated in the northern part of the island of Sumatra and is the largest city in Aceh Province. Figure 1 presents the city location. The topography of the city is flat with no hilly regions. The nearest hilly region is located around $7 \mathrm{~km}$ outside the city's borders. There are several coastal lagoons situated in the northern part of the city. The city was severely damaged by the 2004 Indian Ocean tsunami, which caused the deaths of about 90000 people (Doocy et al., 2007). Prior to the 2004 tsunami, no knowledge was available regarding the potential tsunami that resulted in zero prevention of the hazard. During the rehabilitation and reconstruction process led by Aceh-Nias Rehabilitation and Reconstruction Agency (BRR Aceh-Nias), the city faced serious challenges in relocating its people to a safer area. This resulted in several houses being built in the coastal area. Initially, it was proposed that about $500 \mathrm{~m}$ is left from its coastal line to any settlement, with the aim of using this space for coastal vegetation as a part of the tsunami mitigation; this was named the "green belt" area. This was mentioned in the Master Plan for Rehabilitation and Reconstruction composed by the Indonesia Development and Planning Agency (BAPPENAS, 2005). The 14-year rehabilitation and reconstruction process until 2018 has failed to make it happen.

At present, the coastal population of the city is growing significantly due to return migration from the affected community and more affordable land prices and house rent fees in the coastal area compared to other places in the city 


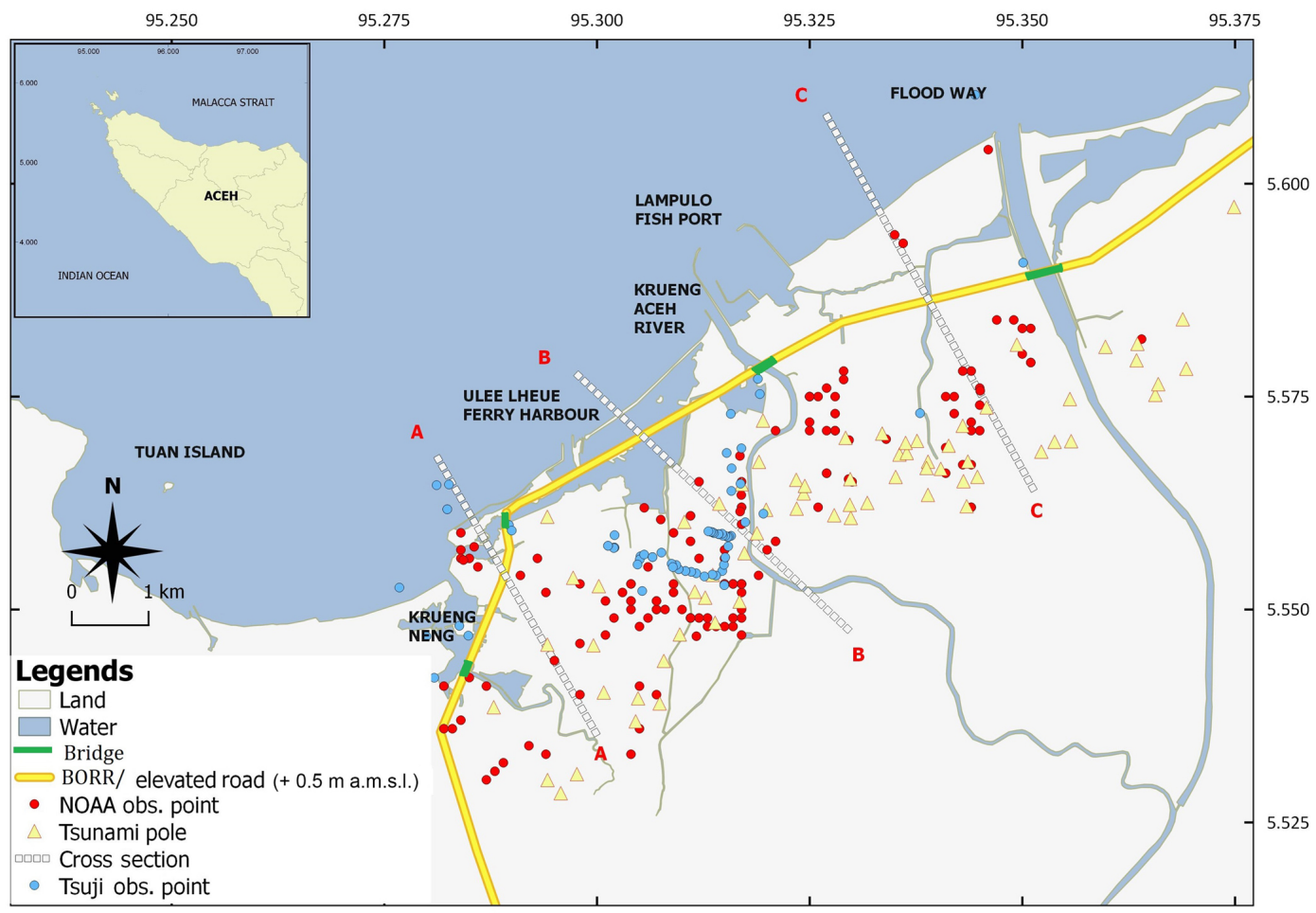

Figure 1. The study area. The elevated road (yellow line) is part of the city's development planning documents. There are 139 points of the 2004 tsunami heights measured by NOAA (red dots) (NOAA, 2018) and 56 locations of tsunami poles representing water marks based on eyewitness accounts (yellow triangles).

(Syamsidik et al., 2017). Figure 1 presents the study area of this research. In Fig. 1, several tsunami flow depth data for this city, published by NOAA, are presented by red dots (NOAA, 2018); data from Tsuji et al. (2006) are indicated by blue dots. Tsunami poles are represented by yellow triangles. These flow depths were later incorporated in the tsunami numerical results' validation. Figure 2 presents the conditions of the coastal area of Banda Aceh based on an aerial image captured by a drone in February 2018. There is a $7 \mathrm{~km}$ revetment structure constructed along the city coast to immediately recover the eroded coastline and to create a barrier between the sea and ponds. The revetment was completed in 2010. Later in 2015, the government constructed a road transect at the leeward of the revetment; however, since the revetment is often being overtopped by waves, the road is frequently damaged by the waves. Figure 3 presents the revetment structure and the road behind the revetment.

New spatial planning and regulation of the city was released in 2009. This was modified in 2012 to accommodate the tsunami reconstruction process along with a few ideas to mitigate the impacts of disasters such as tsunamis; however, no concrete measures were included in the spatial planning document to structurally mitigate the tsunami impacts.

Under the revision process of the spatial planning in 2012, the government of Banda Aceh set up a new plan to construct a road due to the traffic congestion in the city. The road

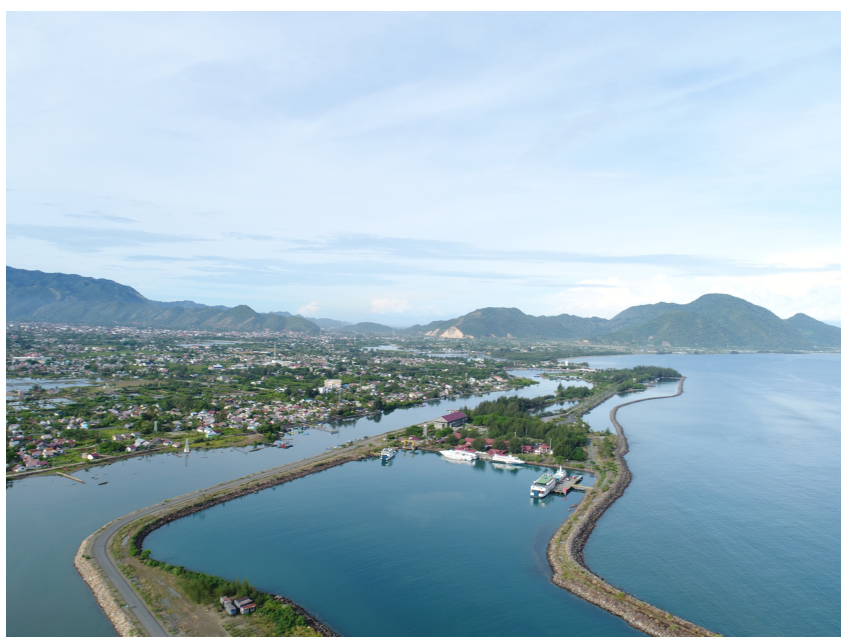

Figure 2. The situation of the coastal area of Banda Aceh based on an aerial image taken in February 2018.

was proposed to aid the mobility of people from the periphery of the city and was named the Banda Aceh Outer Ring Road (BORR). The Japan International Cooperation Agency (JICA) has studied the project. At present, the road project has been put on hold due to an increase in land prices, but it is still in the formal city development document. A series of 


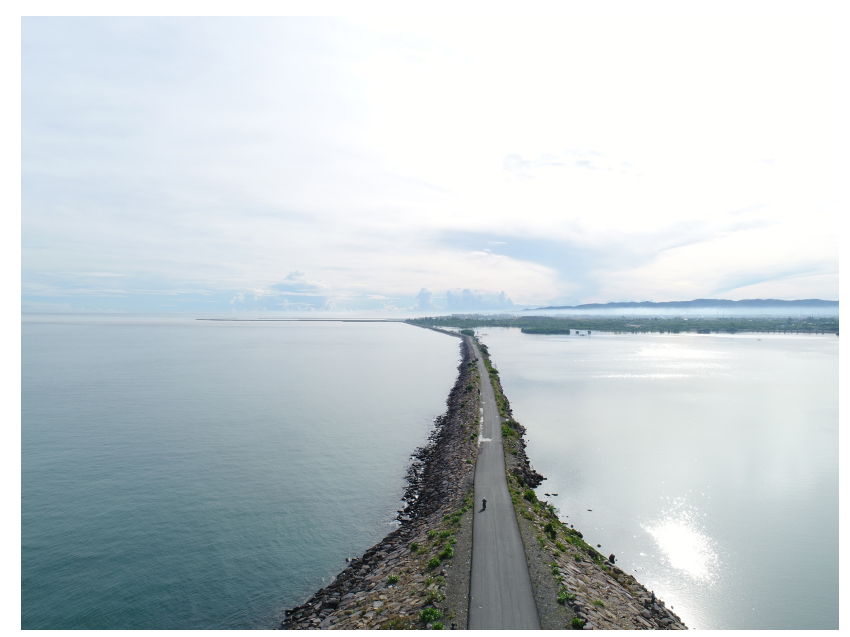

Figure 3. A $7 \mathrm{~km}$ embankment along the coast of Banda Aceh and a road which was constructed at its leeward side (date photo taken: February 2018).

discussions were conducted to include the tsunami mitigation measures in the new planned road. There is an opportunity to modify the design of the road to an elevated road. Some alternatives have been drawn. One of the most intense discussions was to elevate the road to $3 \mathrm{~m}$ from the initial ground; however, the impacts of the planned elevated road on tsunami wave energy are not clear. The BORR transect is presented in Fig. 1. The BORR will pass some area of salt marshes where ponds existed as the major land use type before the tsunami. After the tsunami, large areas of the fishponds were damaged and have never been recovered. In the new spatial planning regulation of the city, the area will be kept as it is and only minor changes are proposed.

\section{Methods}

\subsection{Tsunami numerical simulations}

To measure the impacts of the tsunami waves on the city, two scenarios of the coastal morphology were considered, that is, (1) without BORR and (2) with BORR. Tsunami simulations were performed using the Cornell Multi-grid Tsunami Coupled Model (COMCOT). The COMCOT is a hydrostatic model that uses a leapfrog finite difference method to solve the shallow water equations (SWEs) with a staggered scheme. Both nonlinear and linear shallow water equations can be selected in the model. COMCOT is a two-dimensional horizontal model that calculates the depth-averaged velocities. The linear shallow water equations in the spherical coordinate system used in COMCOT are as follows:

$$
\begin{aligned}
& \frac{\partial \eta}{\partial t}+\frac{1}{R \cos \varphi}\left\{\frac{\partial P}{\partial \psi}+\frac{\partial}{\partial \varphi}(\cos \varphi Q)\right\}=-\frac{\partial h}{\partial t}, \\
& \frac{\partial P}{\partial t}+\frac{g h}{R \cos \varphi} \frac{\partial \eta}{\partial \psi}-f Q=0, \\
& \frac{\partial Q}{\partial t}+\frac{g h}{R} \frac{\partial \eta}{\partial \varphi}+f P=0 .
\end{aligned}
$$

Meanwhile, for nonlinear shallow water equations, COMCOT applies the following equations:

$$
\begin{aligned}
& \frac{\partial \eta}{\partial t}+\frac{1}{R \cos \varnothing}\left\{\frac{\partial P}{\partial \psi}+\frac{\partial}{\partial \varnothing}(\cos \varnothing Q)\right\}=-\frac{\partial h}{\partial t}, \\
& \frac{\partial P}{\partial t}+\frac{1}{R \cos \varnothing} \frac{\partial}{\partial \psi}\left\{\frac{P^{2}}{H}\right\}+\frac{1}{R} \frac{\partial}{\partial \varnothing}\left\{\frac{P Q}{H}\right\} \\
& \quad+\frac{g H}{R \cos \varnothing} \frac{\partial \eta}{\partial \psi}-f Q+F_{x}=0, \\
& \frac{\partial Q}{\partial t}+\frac{1}{R \cos \varnothing} \frac{\partial}{\partial \psi}\left\{\frac{P Q}{H}\right\} \\
& \quad+\frac{1}{R} \frac{\partial}{\partial \varnothing}\left\{\frac{Q^{2}}{H}\right\}+\frac{g H}{R} \frac{\partial \eta}{\partial \varnothing}+f P+F_{y}=0, \\
& f=\Omega \sin \varphi, \\
& F_{x}=\frac{g n^{2}}{H^{7 / 3}} P\left(P^{2}+Q^{2}\right)^{1 / 2}, \\
& F_{y}=\frac{g n^{2}}{H^{7 / 3}} Q\left(P^{2}+Q^{2}\right)^{1 / 2}, \\
& H=\eta+h .
\end{aligned}
$$

Here, $P$ is the volume fluxes in the $x$ direction (east-west direction), which is equal to $h u$, and $Q$ is the volume fluxes in the $y$ direction (south-north direction), which is equal to $h v$, where $h$ is the depth at the grid to the mean sea level and $(u, v)$ are the velocities in the $x$ and $y$ direction, respectively. Furthermore, $\eta$ is the water surface elevation, $(\varphi \psi)$ are the latitude and longitude for the spherical coordinate system, $R$ is the earth radius, $g$ is gravitational acceleration, and $h$ is the water depth at the grid. The component of $-\partial h / \partial t$ denotes the effect of transient seafloor motion; the Coriolis force coefficient due to the earth's rotation is expressed as $f$. Meanwhile, $\Omega$ is for the rotation rate of the earth; $H$ is the total water depth. $F_{x}$ and $F_{y}$ represent the bottom friction in the $\psi$ and $\varphi$ direction, respectively; and $n$ is Manning's roughness coefficient. A complete explanation of the COMCOT module can be referred to in Wang (2009).

\subsection{Computational regions}

We applied six layers of simulation domains, starting from Layer 1 that covers the largest numerical domain including the tsunami source in the Andaman Sea. The innermost layer was Layer 6 that encompasses the city of Banda Aceh and has the smallest size of the grid. The nested grid system also allows us to include the nonlinear effects of the tsunami waves 

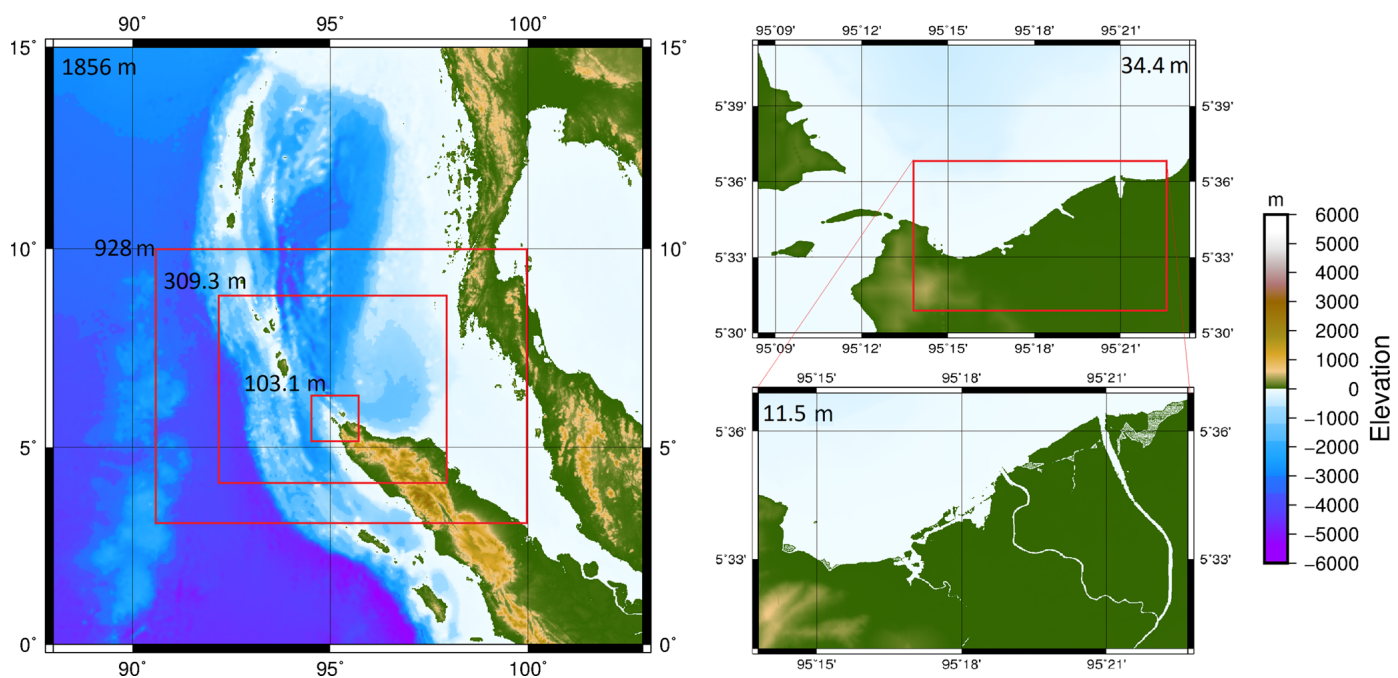

Figure 4. Six simulation layers and the size of the grids (written in each layer) applied in COMCOT.

Table 1. Information on the setup of the six layers for the COMCOT simulations.

\begin{tabular}{|c|c|c|c|c|c|c|c|c|}
\hline Layer & Latitude & Longitude & $\begin{array}{l}\text { Number } \\
\text { of grid }\end{array}$ & Ratio & $\begin{array}{r}\text { Grid } \\
\text { size }(m)\end{array}$ & $\begin{array}{r}\text { Time } \\
\text { step (s) }\end{array}$ & $\begin{array}{l}\text { Manning's roughness } \\
\text { coefficients }\end{array}$ & SWE type \\
\hline 1 & $\begin{array}{r}0.1 \\
14.93\end{array}$ & $\begin{array}{r}88.1 \\
102.8\end{array}$ & 1772 & & 1856 & 0.1 & none & Linear \\
\hline 2 & $\begin{array}{r}3 \\
10\end{array}$ & $\begin{array}{r}91 \\
100\end{array}$ & 1920 & 2 & 928 & 0.05 & none & Linear \\
\hline 3 & $\begin{array}{l}4.08 \\
8.98\end{array}$ & $\begin{array}{l}92.05 \\
97.98\end{array}$ & 3899 & 3 & 309.33 & 0.017 & none & Linear \\
\hline 4 & $\begin{array}{r}5.2708 \\
6.695\end{array}$ & $\begin{array}{l}94.51 \\
95.99\end{array}$ & 3137 & 3 & 103.11 & 0.006 & none & Linear \\
\hline 5 & $\begin{array}{r}5.5 \\
5.69\end{array}$ & $\begin{array}{l}95.14 \\
95.39\end{array}$ & 1426 & 3 & 34.37 & 0.002 & none & Linear \\
\hline 6 & $\begin{array}{l}5.515 \\
5.615\end{array}$ & $\begin{array}{l}95.235 \\
95.378\end{array}$ & 2362 & 3 & 11.5 & 0.001 & $\begin{array}{l}\text { Variable Manning's roughness } \\
\text { coefficients (see Table 3) }\end{array}$ & Nonlinear \\
\hline
\end{tabular}

in the COMCOT simulation. Details of the grid specification are listed in Table 1. All layers in the simulation apply the spherical coordinate system. Fig. 4 presents the simulation layers applied in this study.

Bathymetry data for Layers 1-4 were adopted from the GEBCO data with a resolution of $1 \mathrm{~min}$ for all scenarios. Meanwhile, for Layers 5 and 6, we used the bathymetry data measured by the Geospatial Information Agency of Indonesia for the case of the 2004 tsunami. For the scenarios of 2029, we used the bathymetry data measured by the Aceh Public Works Department in 2007. Topography data measured by the Japan International Cooperation Agency (JICA) in 2005 were used for land topography data. The data were later updated by the Banda Aceh Development and Planning Agency. For the elevated road, the topography data along the transect were altered to $5 \mathrm{~m}$ above mean sea level. The elevations were considered affordable in terms of the construction cost for the city. The structure of the elevated road was assumed to sustain the tsunami wave forces. For this, no scouring processes or altered ground elevation were done due to the tsunami wave forces.

\subsection{Earthquake scenarios}

We used two magnitudes of the earthquake in the simulations, that is, magnitude 8.5 and $9.15 M_{\mathrm{w}}$. Based on the probabilistic tsunami hazards' assessment, the magnitude $8.5 M_{\mathrm{w}}$ could occur once in about 200-300 years (Sengara et al., 2008; Suppasri et al., 2012a, b), or in another study, it was said to have an exceedence return period of 100 years (Burbidge et al., 2009). Here the $8.5 M_{\mathrm{w}}$ earthquake has a focal 

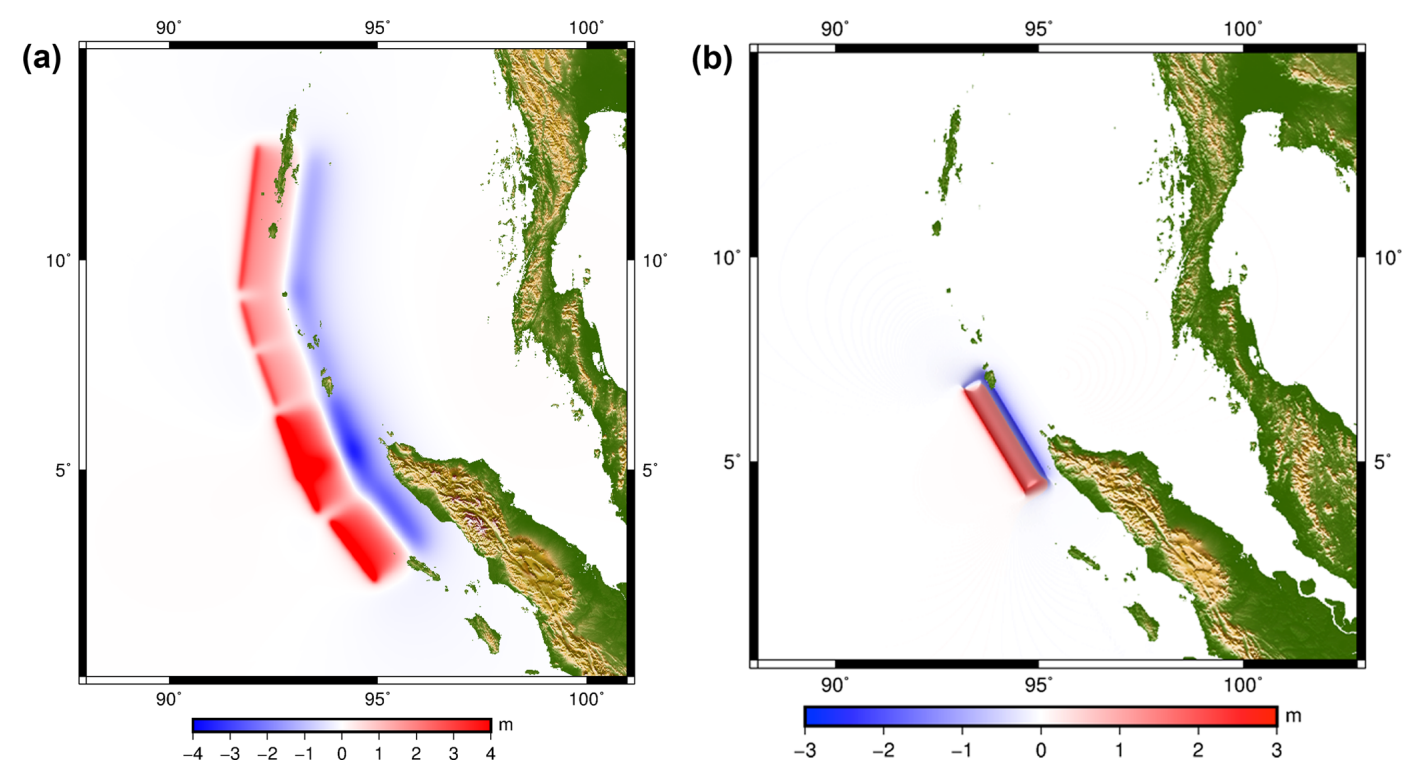

Figure 5. Initial wave forms of generated by the $9.15 M_{\mathrm{W}}$ earthquake as proposed by Koshimura et al. (2009) (a) and by a hypothetical earthquake of $8.5 M_{\mathrm{W}}(\mathbf{b})$.

depth of $10 \mathrm{~km}$, with a displacement of $8.3 \mathrm{~m}$ and dip and slip angles of 8 and $110^{\circ}$, respectively. The strike angle was set to $305^{\circ}$ and the slip angle was $110^{\circ}$. Furthermore, the $8.5 M_{\mathrm{w}}$ fault scenario was set to give maximum impacts on the Banda Aceh coast. Therefore, the location of the fault was moved along the fault lines to find the right location to deliver the maximum impacts. The magnitude $8.5 M_{\mathrm{w}}$ was calculated as a single fault. Meanwhile, the multifault method was adopted for $9.15 M_{\mathrm{w}}$. The fault details of the $9.15 M_{\mathrm{w}}$ followed Koshimura et al. (2009). Dimensions of the rupture area were calculated using Wells and Coppersmith formulae (Wells and Coppersmith, 1994). Deformation of the seafloor caused by the rupture area was calculated following the formulae suggested by Masinha and Smylie (1971) and Okada (1985). Initial sea surface levels as a result of earthquake generation are presented in Fig. 5. The land use for Layer 6 was adopted based on two conditions, that is, (1) land use of the city in 2004 before the Indian Ocean tsunami and (2) land use of the city as in the Banda Aceh spatial planning regulation for 2029. The impacts of the elevated road by imposing two scenarios of the road were then compared, that is, (1) with BORR and (2) without BORR.

\subsection{Data and validation}

There are eight simulations in total, as listed in Table 2. Validation of the simulation was done by comparing the scenario no. 211 with the heights of the tsunami inundation in Banda Aceh as marked by several tsunami poles in the city (Sugimoto et al., 2010). We used Aida functions to validate the numerical results (Aida, 1978) that are based on $K$ and $\kappa$ as follows: $\log K=\frac{1}{n} \sum_{i=1}^{n} \log K_{i}$

$\log \kappa=\sqrt{\frac{1}{n} \sum_{i=1}^{n}\left(\log K_{i}\right)^{2}-(\log K)^{2}}$,

$K_{i}=\frac{H_{\mathrm{obs}-i}}{H_{\mathrm{sim}-i}}$

where $H_{\mathrm{obs}-i}$ is the observed tsunami inundation height or depth at point $i$ and $H_{\mathrm{sim}-i}$ is the tsunami inundation height or depth based on the simulation at point $i$. The value of $\kappa$ represents the variance of $K_{i}$. Meanwhile, $K$ represents the mean of $K_{i}$. Takeuchi et al. (2005) suggested that the model results are in good agreement if $0.8 \leq K \leq 1.2$ and $\kappa \leq 1.60$. Another study also suggests that if the value of $\kappa$ is valid based on the given criteria and the value of $K$ is slightly $>1.05$, the results can also be classified as "good enough" (Koshimura et al., 2009).

Variations in the land use were included by modifying the Manning roughness coefficients based on land cover of the area. Table 3 presents the values of the Manning coefficients included in the simulations as suggested by Li et al. (2012). Distribution of the Manning coefficients used in the two types of land use, that is, the 2004 and 2029 land use, is presented in Figs. 6 and 7, respectively. 
Table 2. Scenarios of the numerical simulations.

\begin{tabular}{llcc}
\hline $\begin{array}{l}\text { Magnitude } \\
\left(M_{\mathrm{W}}\right)\end{array}$ & BORR scenario & $\begin{array}{c}\text { Land use } \\
\text { in year }\end{array}$ & $\begin{array}{c}\text { Code of } \\
\text { simulations }\end{array}$ \\
\hline 8.5 & Without BORR & 2004 & no. 111 \\
& 2029 & no. 112 \\
\cline { 2 - 4 } & With BORR & 2004 & no. 121 \\
& Without BORR & 2004 & no. 211 \\
& & 2029 & no. 212 \\
\hline \multirow{2}{*}{9.15} & With BORR & 2004 & no. 221 \\
& & 2029 & no. 222 \\
& & & \\
\end{tabular}

Table 3. Manning's coefficients based on land cover of the area $(\mathrm{Li}$ et al., 2012).

\begin{tabular}{lr}
\hline Land use & $\begin{array}{r}\text { Manning's roughness } \\
\text { coefficient }(n)\end{array}$ \\
\hline Coastal vegetation & 0.035 \\
Fish ponds & 0.017 \\
Building & 0.04 \\
Sea & 0.013 \\
Soil & 0.02 \\
\hline
\end{tabular}

\section{Results}

\subsection{Validation of the 2004 Indian Ocean tsunami}

To validate the result, we used the 2004 Indian Ocean tsunami case with the land use form adopted from the situation before the tsunami (without BORR) or scenario no. 211 as listed in Table 2. Validations of the initial wave forms and offshore tsunami wave propagation have been done in several studies (Koshimura et al., 2009; Suppasri et al., 2011; Suppasri et al., 2010). The studies used the water level around a transect in the Andaman Sea captured by the Jason-1 satellite about $2 \mathrm{~h}$ after the $9.15 M_{\mathrm{w}}$ earthquake on 26 December 2004. The agreement of the simulated offshore tsunami wave heights was found to be good in the two aforementioned studies. For the tsunami inundation heights and depths, the results of the validation are presented in Table 4 using Aida parameters calculated based on Eqs. (11)-(13). Based on the results, we confirmed that the simulated reports are in accordance with the observed data provided by the NOAA data and tsunami poles in the city.

\subsection{Impacts of the elevated roads}

Using the two magnitudes of earthquakes to generate tsunami waves, the impacts of BORR were tested. The reduction of tsunami velocity due to obstacles, both natural and man-made structures, has been proven correct by previous research (e.g., Nandasena et al., 2012; Matsutomi and

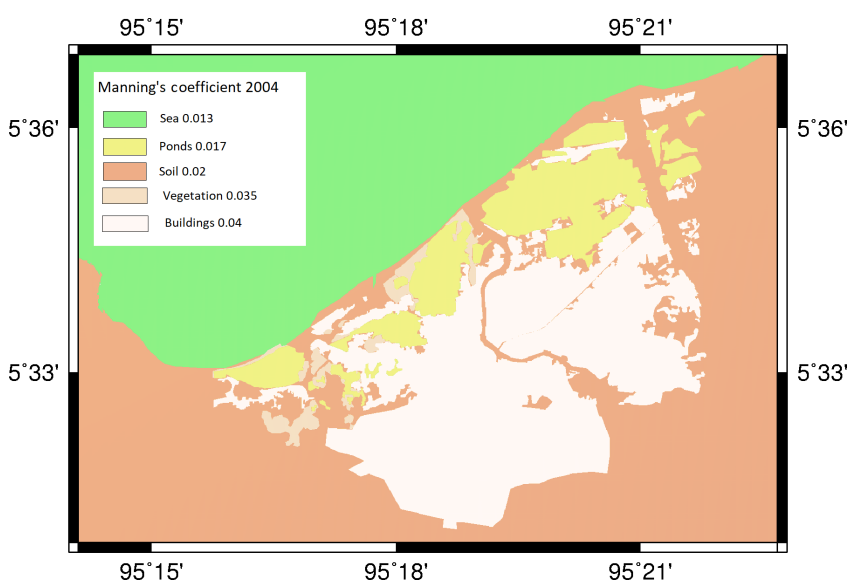

Figure 6. Distribution of Manning's coefficients used in the simulation for land use types in 2004 (before the 2004 Indian Ocean tsunami).

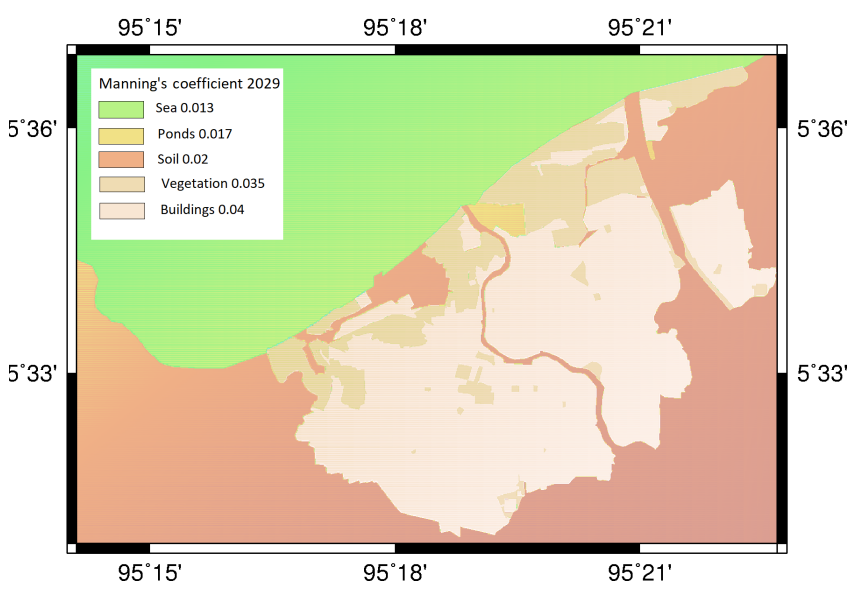

Figure 7. Distribution of Manning's coefficients used in simulations for land use types as described in the Banda Aceh spatial planning regulation aimed to be implemented until 2029.

Okamoto, 2010). Sea walls as well as other types of onshore structures will reduce the energy of the tsunami, mainly by reducing the wave's velocity. Froude numbers will be reduced as the tsunamis hit natural barriers or other solid manmade structures. The following section elucidates a series of comparisons of the maximum wave run-up in Banda Aceh.

\subsubsection{Magnitude 8.5 $M_{\mathrm{w}}$}

The distribution of the tsunami flow depths caused by the $8.5 M_{\mathrm{w}}$ earthquake is presented in Fig. 9. Due to the BORR structure, the area of the inundation could be reduced by about $22 \%$. Table 5 provides comparisons for all the scenarios for the tsunami inundation area. It is observed that the impacts of the land use changes are not significant enough to further reduce the tsunami inundation area. The 2029 land use, if combined with BORR, will only further reduce the 
Table 4. The validation results of the simulation using Aida parameters for scenario no. 211.

\begin{tabular}{lcr}
\hline Model results & \multicolumn{2}{c}{ Aida parameters } \\
\cline { 2 - 3 } & $K$ & $k$ \\
\hline NOAA data $(n=139)$ & 1.18 & 1.42 \\
Tsunami pole data $(n=56)$ & 0.79 & 1.50 \\
Tsuji et al. $(2006)(n=50)$ & 0.68 & 1.61 \\
\hline
\end{tabular}

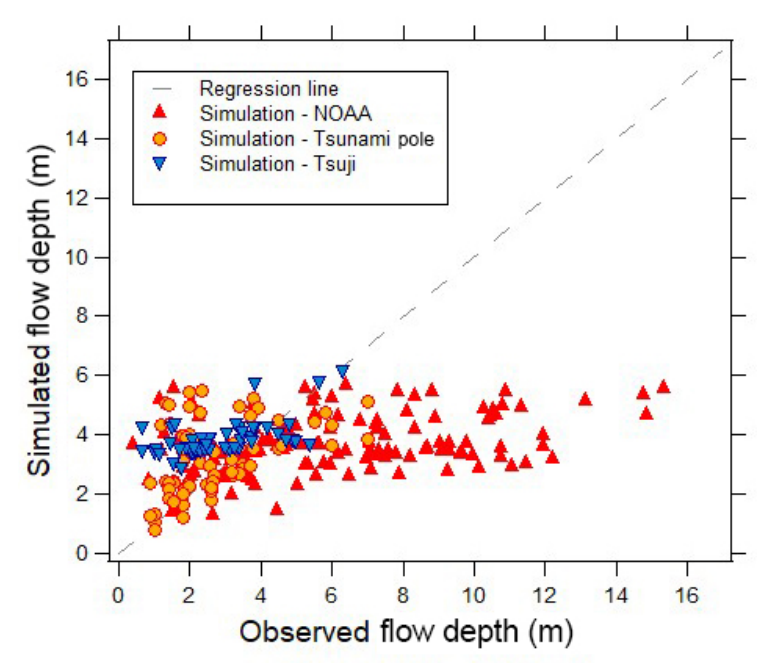

Figure 8. Comparisons between measured tsunami wave heights and simulation results.

tsunami inundation area by about $1.2 \%$. The BORR coupled with land use changes can reduce the inundation area that is deeper than $2 \mathrm{~m}$ by about $25 \%$.

Figure 12 provides comparisons of the tsunami wave heights for the three transects indicated in Fig. 1 that are relatively perpendicular to the coastline. At all transects, we could observe that the magnitude $8.5 M_{\mathrm{w}}$ could still generate tsunami heights of about $3 \mathrm{~m}$ along the coastline. Tsunamis could cover the BORR structure, in particular, at the area around transect $\mathrm{B}$. Interestingly, the tsunami inundation area behind the BORR structure at transect B is mostly located around the salt marsh area where no inhabitants reside. At the other transects the tsunami waves could be stopped by the BORR structure, provided that the structure can sustain the stability test produced by the waves. Without BORR (scenarios no. 111 and no. 112), the tsunami wave could reach about $2 \mathrm{~km}$ from the coastline as presented in transect A (Fig. 12). With BORR (scenarios no. 121 and no. 122), the tsunami run-up could be reduced to an area of about $0.8 \mathrm{~km}$ from the coastline (see transect B in Fig. 12). For the area where the bridges are located, the tsunami waves could travel about $6 \mathrm{~km}$ along the main rivers. Considering that the river embankment is higher than $1.5 \mathrm{~m}$ from the original soil surface, the tsunami wave along the river will be able to stay within the river's main channel. At present, the river embankment along the city is $3 \mathrm{~m}$ above the soil surface as a result of several projects undertaken between 1989 and 1992.

This was also proven true in the case of dike impacts on reducing the tsunami wave heights during the 2011 Tohoku earthquake and tsunami in the city of Ishinomaki in Japan (Takagi and Bricker, 2014). Interestingly, the inland structures as represented by the elevated road managed to stop the tsunami inundation. This was possible as the elevated road could reduce the velocity of the tsunami wave.

\subsubsection{Magnitude 9.15 $M_{\mathrm{w}}$}

Figure 10 presents a comparison of the maximum tsunami inundation depths based on the land use types as in the conditions before the 2004 Indian Ocean tsunami without BORR to the conditions with BORR for the earthquake of magnitude $9.15 M_{\mathrm{w}}$. The comparison clearly indicates the changes made by the BORR in terms of tsunami inundation depths. In front of BORR, the tsunami waves could be higher compared to the landward area of the road. In contrast, the tsunami inundation area could be $8.60 \%$ smaller if the road were constructed.

Similar effects of the BORR structures on the distribution of tsunami wave depths are presented in Fig. 11 for the 2029 land use planning. Using the 2029 planned land use types with BORR, the wave heights could be decreased in the area behind the road. In contrast, if we compare Fig. 10a and Fig. 11a, we notice that the impacts of changing land use types as is planned for 2029 will not have any significant difference in terms of the tsunami inundation depths and areas. Therefore, the changes of the land use alone are not sufficient to reduce the adverse impacts of the tsunami waves if the magnitude of the earthquake is 9.15. BORR coupled with the land use change (for 2029) could reduce the tsunami inundation area by about $9.7 \%$.

All observed transects reveal similar effects of the BORR on the maximum inundation depths. The depths could be decreased after the BORR structure. Just at the leeside of the BORR structure, the depths will be decreased to about $4 \mathrm{~m}$ with the structure for the earthquake of magnitude $9.15 M_{\mathrm{w}}$. This is about $28.5 \%$ lower than the situation without BORR. Figure 12 presents the comparison of maximum tsunami inundation depths for all the simulation scenarios for transects $\mathrm{A}, \mathrm{B}$, and $\mathrm{C}$.

Maximum wave velocities in the area behind the proposed elevated road are listed in Table 6 . The results proved that the structure could significantly stop the tsunami in the case of the earthquake of magnitude $8.5 M_{\mathrm{w}}$. For the earthquake of magnitude $9.15 M_{\mathrm{w}}$, the maximum velocities can be reduced by about $50 \%$ provided the land use is still the same as in 2004 and about $72 \%$ if the land use for 2029 is implemented. Therefore, the modification of the land use combined with the BORR structure could potentially reduce the damage of 

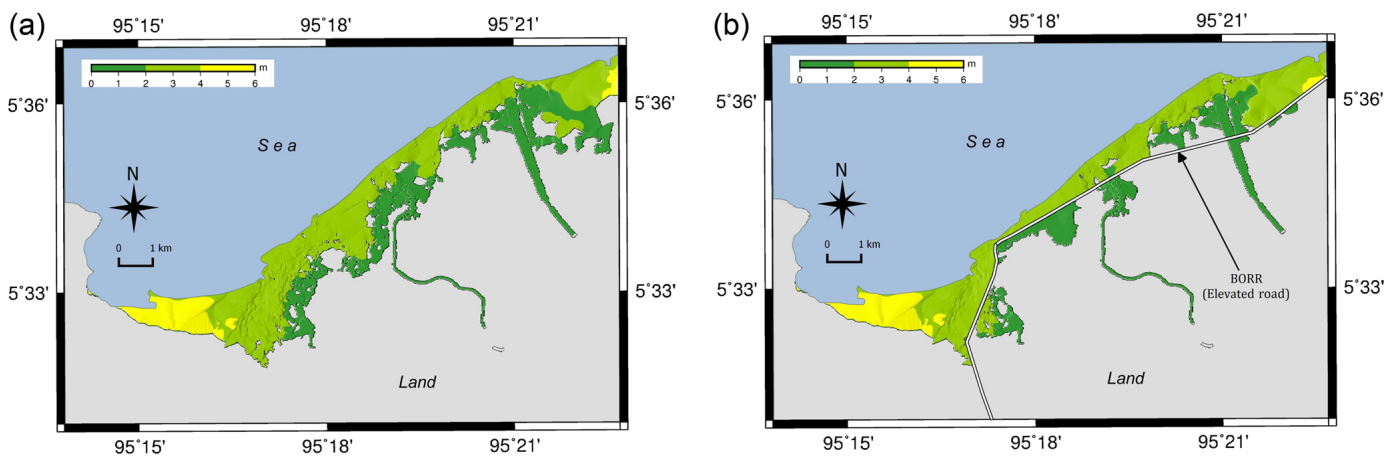

Figure 9. Comparison of maximum tsunami inundation depths generated by the $8.5 M_{\mathrm{W}}$ earthquake with conditions without BORR (a) and with BORR(b).
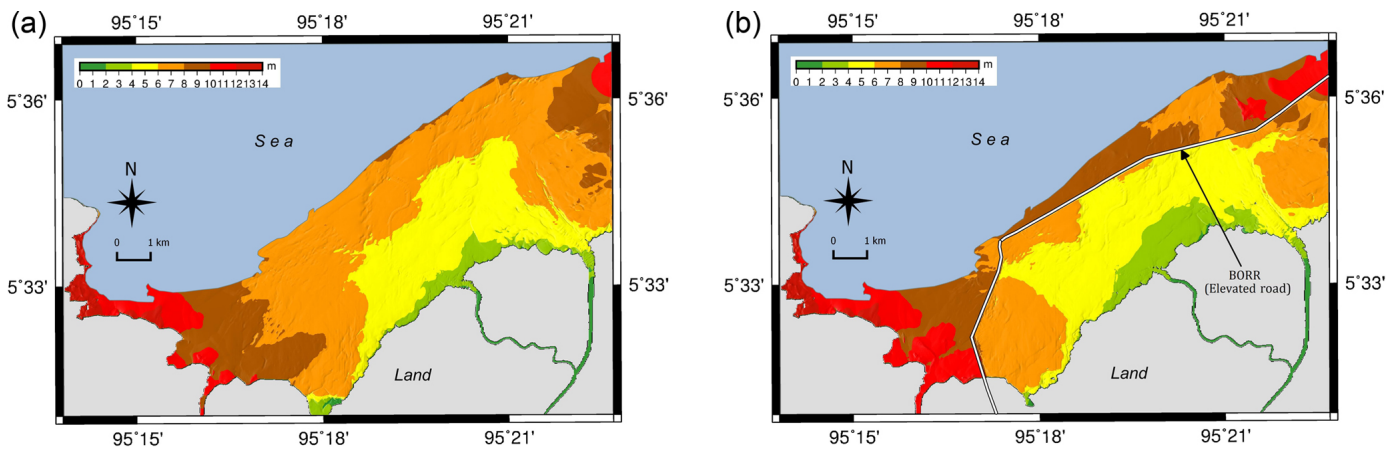

Figure 10. Maximum tsunami wave depths based on the $9.15 M_{\mathrm{W}}$ earthquake without BORR (a) and with BORR (b). The simulations are shown for the land use type before the 2004 Indian Ocean tsunami.

Table 5. Comparisons of tsunami inundation area based on the simulations.

\begin{tabular}{llrrrr}
\hline $\begin{array}{l}\text { Magnitude } \\
\text { of } \\
\text { earthquake }\end{array}$ & Land use type & $\begin{array}{r}\text { Total area of } \\
\text { inundation } \\
\text { (ha) }\end{array}$ & $\begin{array}{r}\text { Area of } \\
\text { inundation } \\
\text { deeper than } 2 \mathrm{~m} \\
\text { (ha) }\end{array}$ & $\begin{array}{r}\% \text { of total } \\
\text { decrease }\end{array}$ & $\begin{array}{r}\% \text { of } \\
\text { decrease for } \\
\text { area deeper } \\
\text { than } 2 \mathrm{~m}\end{array}$ \\
\hline $8.5 M_{\mathrm{W}}$ & 2004 without BORR & 1591.73 & 998.89 & -21.33 & -25.28 \\
& 2004 with BORR & 1252.20 & 746.38 & & -24.29 \\
\cline { 2 - 6 } & 2029 without BORR & 1553.03 & 979.58 & -22.51 & \\
\hline $9.15 M_{\mathrm{W}}$ & 2029 with BORR & 1203.47 & 741.67 & & -43.02 \\
& 2004 without BORR & 4654.27 & 3722.60 & -8.60 & \\
\cline { 2 - 6 } & 2029 with BORR & 4254.17 & 2121.17 & & -44.09 \\
& 2029 with BORR & 4148.91 & 1991.13 & & -9.66 \\
\hline
\end{tabular}



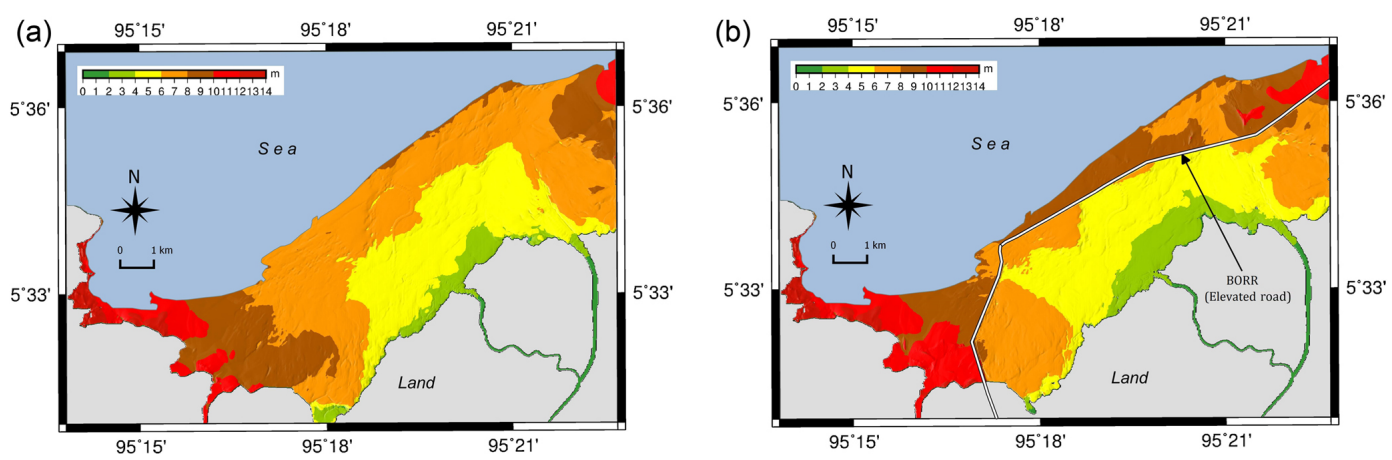

Figure 11. Maximum tsunami wave depths based on the $9.15 M_{\mathrm{W}}$ earthquake without BORR (a) and with BORR (b). The simulations are based on the 2029 land use planning of Banda Aceh.

Table 6. Maximum velocities after the elevated road structures.

\begin{tabular}{lll|lr|lr|rr}
\hline \multirow{2}{*}{ Transect } & \multicolumn{2}{c}{ Max. velocities for $8.5 M_{\mathrm{W}}\left(\mathrm{m} \mathrm{s}^{-1}\right)$} & \multicolumn{2}{c}{ Max. velocities for $9.15 M_{\mathrm{W}}\left(\mathrm{m} \mathrm{s}^{-1}\right)$} \\
\cline { 2 - 8 } & \multicolumn{2}{l|}{ Without BORR } & \multicolumn{2}{|c|}{ With BORR } & Without BORR & \multicolumn{2}{c}{ With BORR } \\
\cline { 2 - 8 } & 2004 & 2029 & 2004 & 2029 & 2004 & 2029 & 2004 & 2029 \\
\hline A & 4.52 & 3.80 & 0.00 & 0.00 & 4.85 & 4.98 & 2.85 & 1.40 \\
B & 3.20 & 1.30 & 0.25 & 0.22 & 4.42 & 5.15 & 1.90 & 1.51 \\
C & 0.45 & 0.41 & 0.00 & 0.00 & 4.92 & 4.60 & 2.35 & 1.25 \\
\hline
\end{tabular}

the tsunami waves by about $22 \%$ compared to the land use of 2004.

\section{Discussions and limitations of the study}

The effects of elevated roads to limit tsunami inundation, demonstrated in the case of the 2011 Great East Japan tsunami, has inspired this research for Banda Aceh. This city was severely damaged by the 2004 Indian Ocean tsunami. The inland structures and modification of the land use could help mitigate the impacts of tsunami waves. In our study, the proposed elevated road (BORR), planned to be constructed in Banda Aceh, which will be relatively parallel to the coastline, is expected to reduce the tsunami wave energy. This research found that the elevated road could effectively mitigate the tsunami generated by the earthquake of magnitudes 8.5 and $9.15 M_{\mathrm{w}}$, generated around the Andaman Sea, with different percentages of reduction. The larger the magnitude of the earthquake, the less effective the reduction in the tsunami wave energy through BORR coupled with land use changes will be. As land use is a dynamic variable, it is important to note that certain land use controls to ensure the effectiveness of tsunami reduction are necessary.

Based on the land use plan of Banda Aceh for 2029, the city will reclaim a certain area around the coastal lagoons amd salt marshes and will preserve some areas of the lagoons as they are at present (salt marshes with mangrove forest). The lagoons play a significant role as they function as dug pools behind the revetment structures. In the case of overflow, the lagoons have the potential to reduce the tsunami wave energy, similar to that observed in the Teizan canal of the Tohoku area during the 2011 tsunami (Tokida and Tanimoto, 2014). The mangrove forests are also crucial for the reduction of the energy of tsunami waves, as proven by several research studies (see Yanagisawa et al., 2009; Iimura and Tanaka, 2012; Tanaka et al., 2014; Strusińska-Correia et al., 2013). In the case of an inland embankment structure (such as the BORR structure in this study), the seaward coastal forest can reduce the possibility of overflow events. Furthermore, the landward forest could reduce the drag force behind the forest (Igarashi and Tanaka, 2018) and stop the tsunami debris. Therefore, it is important to preserve the area of mangrove forests and salt marshes.

Tsunami wave heights, as high as $3 \mathrm{~m}$, can be reduced up to $1.5 \mathrm{~m}$ behind the structure of the elevated road, provided that the road structure is not breached. The concept of elevating the road to help mitigate impacts of the tsunami could be regarded as a concept of co-beneficial development, simultaneously integrating the traffic demands and tsunami mitigation. A similar concept was observed in Sri Lanka to check the possibilities of elevating the train railway to use an embankment type of railway to reduce the intensity of tsunamis (Samarasekara et al., 2017). Adopting the principles of tsunami mitigation in the existing plan of the structure could also derive other impacts, such as the need to modify the city drainage system. 
(a) Maximum wave heights - transect A

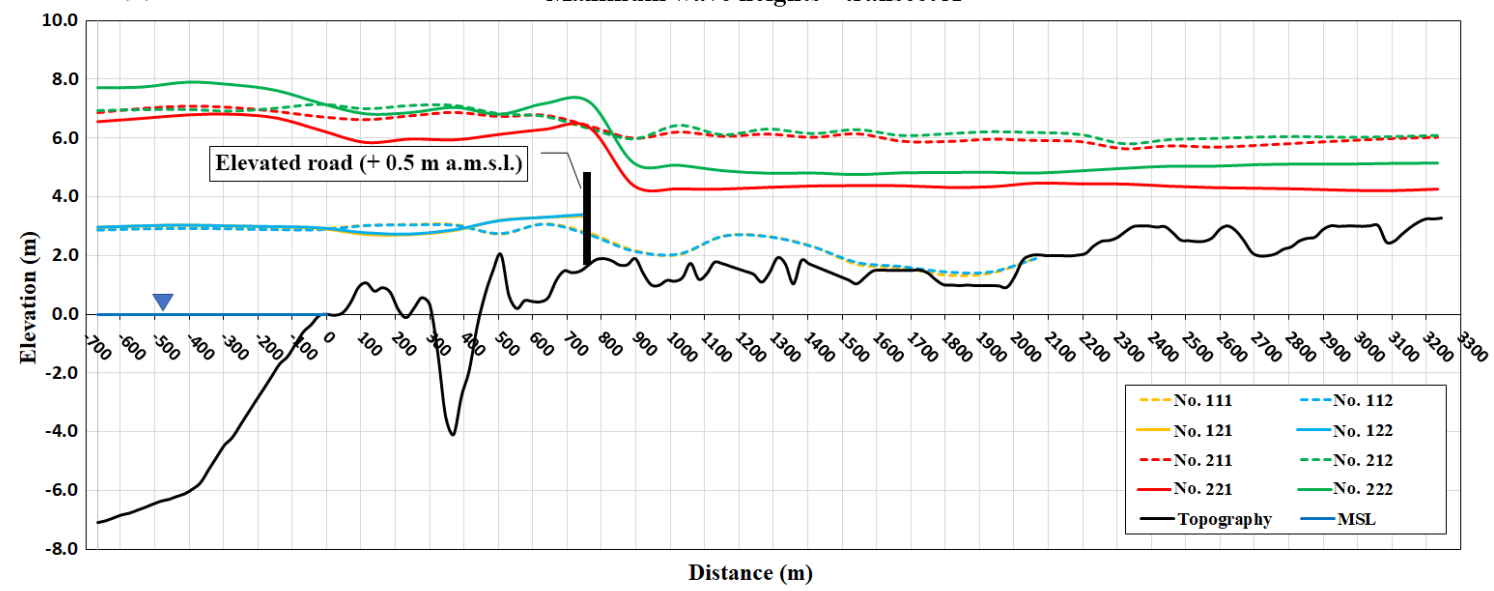

(b)

Maximum wave heights - transect B

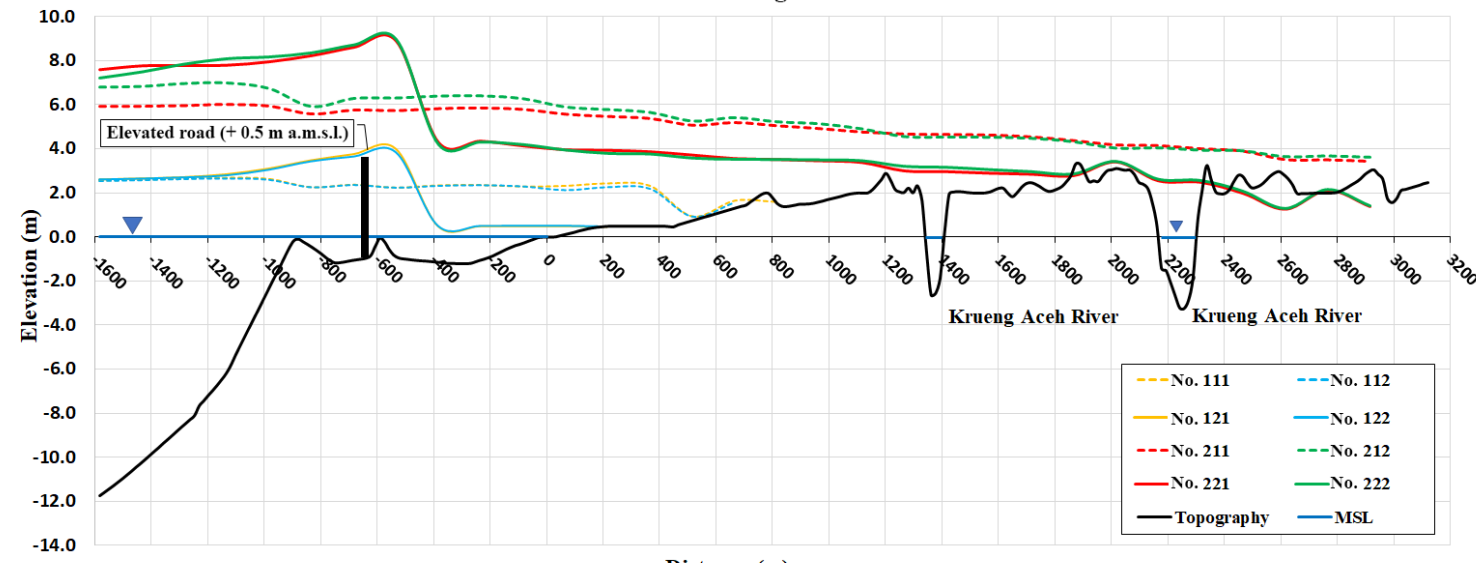

Distance (m)

(c) Maximum wave heights - transect $\mathrm{C}$

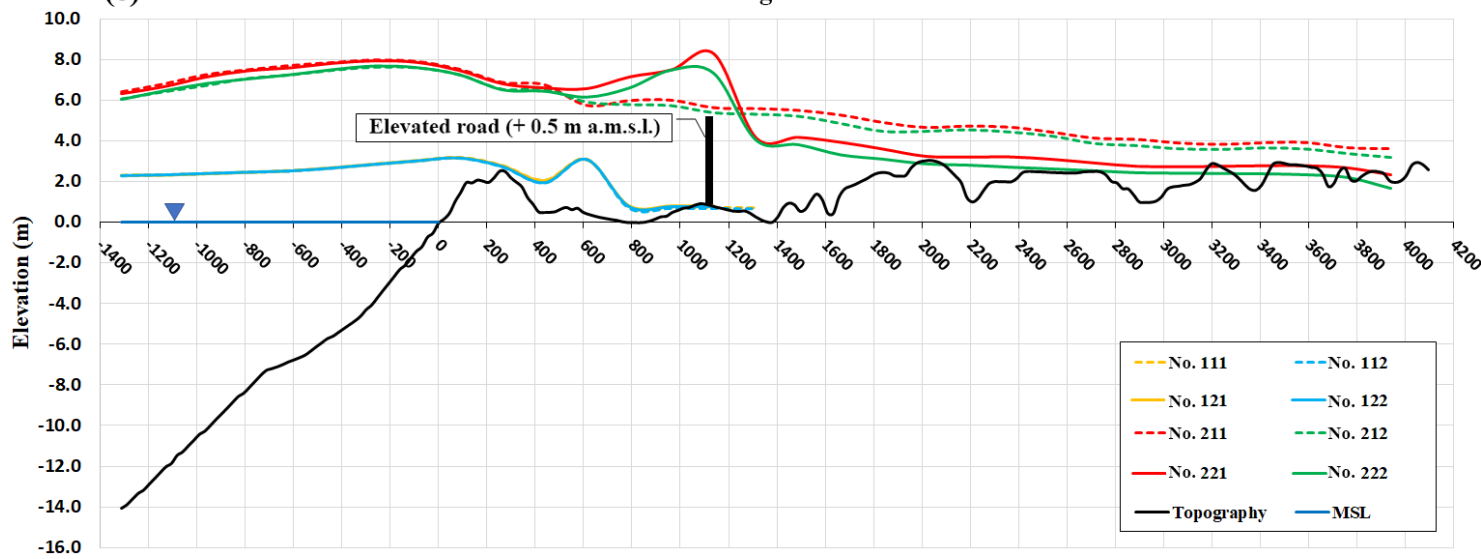

Distance (m)

Figure 12. The comparison of tsunami wave heights at transects A, B, and C based on scenarios with and without BORR. 
This study has certain limitations. Our proposed elevated road structure is an embankment type that has the elevation of $5 \mathrm{~m}$ above mean sea level. This type of structure will soon be covered by the tsunami waves if the magnitude of the earthquake is larger than $8.5 M_{\mathrm{w}}$. Since the waves are characterized as long waves, scouring effects may occur immediately after the overflowing process. Furthermore, the leeside of the embankment will be easily damaged in the case of overflowing at a rubble-mound-type embankment (AnielQuiroga et al., 2018). The extreme difference of the hydrostatic pressures between the seaward and leeward direction of the BORR should also be considered. This could destabilize the structure (Ozer et al., 2015). This study excluded the damage that occurred due to the overflow process and scouring. Moreover, the density of the buildings was not considered as a parameter that could fluctuate the Manning roughness coefficients as suggested by previous research (Kotani et al., 1998; Dutta et al., 2007).

\section{Conclusions and recommendations}

This study explores the possibility of mitigating the impacts of future tsunamis on Banda Aceh based on eight scenarios of numerical simulations. We used two magnitudes of earthquakes that generate tsunamis, that is, magnitudes 8.5 and $9.15 M_{\mathrm{w}}$. An elevated road and the land use planning for 2029 were included in the simulations to test the possibility of adopting the concept of a co-beneficial structure for tsunami mitigation. A tsunami multilayer defense system as applied by the Tohoku region after the 2011 Great East Japan Earthquake and Tsunami cannot be afforded in the tsunamiprone cities in developing countries, such as Banda Aceh. There is a potential way to include structural tsunami mitigation by modifying the coastal area profile. One of the possibilities for Banda Aceh is to elevate a planned road parallel to the coast, namely, the Banda Aceh Outer Ring Road (BORR). Based on the simulations, the elevated road, by reclaiming $5 \mathrm{~m}$ above mean sea level, could reduce the inundation area by about $9 \%$ and $22 \%$ in the case of 9.15 and $8.5 M_{\mathrm{w}}$ earthquakes, respectively. The wave heights and the wave velocities could also be reduced using the elevated road structures. Notably, land use planning alone without BORR will cause insignificant reduction in the tsunami wave heights and tsunami inundation area. Therefore, the elevated road coupled with the 2029 land use planning is expected to reduce the tsunami risks for the city, if implemented.

Based on the results, we recommend the city of Banda Aceh to conduct several tsunami mitigation measures, as follows:

a. Control the increase in population and settlements around the coastal area. b. Control the land use of the coastal area, in particular, the area in front of the planned BORR transect, and maintain it as a nonresidential area.

c. Adopt the elevated roads in the BORR construction as this will significantly help the city to cope with future tsunamis.

d. Preserve the salt marsh area around the coast, as this would also help to reduce the tsunami impacts. The salt marsh area could also be planted with mangroves or other brackish water vegetation that would increase the Manning roughness coefficients of the area. This further will reduce the speed of the tsunami waves.

Data availability. Raw data belong to the Banda Aceh Municipality (BAPPEDA Banda Aceh). Authors are not authorized to publicly share the data directly.

Author contributions. S is the principal investigator of this research and led the analysis and writing process. T simulated all the scenarios of numerical models. AS helped to validate the simulation result and corrected this article. ML and MA conducted bathymetry surveys and digitized BA land use. LKC is a US research collaborator for this research project funded by PEER USAID.

Competing interests. The authors declare that they have no conflict of interest.

Acknowledgements. The authors are grateful for the research grant from the Partnership Enhanced Engagement in Research (PEER) Cycle 5 sponsored by the USAID and National Academies of Sciences, Engineering, and Medicines of United States (NAS) under research grant no. 5-395, with the title "Incorporating climate change induced sea level rise information into coastal cities' preparedness toward coastal hazards", with NAS subaward no. 2000007546. A visit of Anawat Suppasri (co-author of this article) to Banda Aceh and fine-tuning of the paper took place under the World Class Professor Program (WCP) Scheme B, promoted by the Ministry of Research, Technology, and Higher Education of Indonesia (RISTEKDIKTI) in 2018 (contract no. 123.41/D2.3/KP/2018). Digitizing certain spatial data for land use and elevated roads was done under the PKLN of RISTEKDIKTI Program grant no. SK.60/UN11.2/SP3/2018 Year 2018, with the title "Mitigating Impacts Of Tsunami Waves On Coastal Structures And Harbor Facilities". The publication of this paper is also funded by IRIDeS of Tohoku University, Japan.

Edited by: Maria Ana Baptista

Reviewed by: two anonymous referees 


\section{References}

Abe, T., Goto, K., and Sugawara, D.: Relationship between the maximum extent of tsunami sand and the inundation limit of the 2011 Tohoku-oki tsunami on the Sendai Plain, Japan, Sediment. Geol., 282, 142-150, 2012.

Aida, I.: Reliability of a tsunami source model derived from fault parameters, J. Phys. Earth, 26, 57-73, 1978.

Aniel-Quiroga, I., Vidal, C., Lara, J. L., Gonzalez, M., and Sainz, A.: Stability of rubble-mound breakwaters under tsunami first impact and overflow based on laboratory experiments, Coast. Eng., 135, 39-54, 2018

BAPPENAS (Indonesia National Development Planning Agency): Master plan of Aceh-Nias rehabilitation and reconstruction: the main book, BAPPENAS, Jakarta, 2005.

Burbidge, D. R., Cummins, P. R., Mleczko, R., Latief, H., Mokhtari, M., Natawidjaja, D., and Rajendran, C. P.: A Probabilistic Tsunami Hazard Assessment of the Indian Ocean Nations, available at: https://d28rz98at9flks.cloudfront.net/68717/68717. pdf (last access: 10 July 2018), 2009.

Chen, J., Jiang, C., Yang, W. , and Xiao, G.: Laboratory study on protection of tsunami-induced scour by offshore breakwaters, Nat. Hazards, 81, 1229-1247, 2016.

Doocy, S., Rofi, A., Moodie, C., Spring, E., Bradley, S., Burnham, G., and Robinson, C.: Tsunami mortality in Aceh Province, Indonesia, B. World Health Organ., 85, 273-278, 2007.

Dutta, D., Alam, J., Umeda, K., Hayashi, M., and Hironaka, S.: A two-dimensional hydrodynamic model for flood inundation simulation: a case study of the Lower Mekong river basin, Hydrol. Process., 21, 1223-1237, 2007.

Goto, K., Chaque-Goff, C., Goff, J., and Jaffe, B.: The future of tsunami research following the 2011 Tohoku-oki event, Sediment. Geol., 282, 1-13, 2012a.

Goto, K., Fujima, K., Sugawara, D., Fujino, S., Imai, K., Tsudaka, R., Abe, T., and Haraguchi, T.: Field measurements and numerical modeling for the run-up heights and inundation distances of the 2011 Tohoku-oki tsunami at Sendai Plain, Japan, Earth Planets Space, 64, 1247-1257, 2012b.

Government of Banda Aceh: Report on Spatial Planning of Banda Aceh 2009-2029, Banda Aceh, 2009.

Guler, H. G., Baykal, C., Arikawa, T., and Yalciner, A. C.: Numerical assessment of tsunami attack on a rubble mound breakwater using OpenFOAM, Appl. Ocean Res., 72, 76-91, 2018.

Horspool, N., Pranantyo, I., Griffin, J., Latief, H., Natawidjaja, D. H., Kongko, W., Cipta, A., Bustaman, B., Anugrah, S. D., and Thio, H. K.: A probabilistic tsunami hazard assessment for Indonesia, Nat. Hazards Earth Syst. Sci., 14, 3105-3122, https://doi.org/10.5194/nhess-14-3105-2014, 2014.

Igarashi, Y. and Tanaka, N.: Effectiveness of compound defense system of sea embankment and coastal forest against a tsunami, Ocean Eng., 151, 246-256, 2018.

Iimura, K. and Tanaka, N.: Numerical simulation estimating effects of tree density distribution in coastal forest on tsunami mitigation, Ocean Eng., 54, 223-232, 2012.

Koshimura, S., Oie, T., Yanagisawa, H., and Imamura, F.: Developing fragility functions for tsunami damage estimation using numerical model and post-tsunami data from Banda Aceh, Indonesia, Coast. Eng. J., 51, 243-273, 2009.
Koshimura, S., Hayashi, S., and Gokon, H.: The impact of the 2011 Tohoku Earthquake tsunami disaster and implications to the reconstruction, Soils Found., 54, 560-572, 2014.

Kotani, M., Imamura, F., and Shuto, N.: Tsunamu run-up simulation and damage estimation by using geographical information system, Proceedings of Coastal Engineering JSCE, 45, 356-360, 1998 (in Japanese).

Kreibich, H., Piroth, K., Seifert, I., Maiwald, H., Kunert, U., Schwarz, J., Merz, B., and Thieken, A. H.: Is flow velocity a significant parameter in flood damage modelling?, Nat. Hazards Earth Syst. Sci., 9, 1679-1692, https://doi.org/10.5194/nhess-91679-2009, 2009.

Lavigne, F., Paris, R., Grancher, D., Wassmer, P., Brunstein, D., Vautier, F., Leone, F., Flohic, F., Coster, B. D., Gunawan, T., Gomez, C., Setiawan, A., Cahyadi, R., and Fachrizal: Reconstruction of tsunami inland propagation on December 26, 2004 in Banda Aceh, Indonesia, through field investigations, Pure Applied Geophysic, 166, 259-281, 2009.

Li, L., Qiu, Q., and Huang, Z.: Numerical modeling of the morphological change in Lhok Nga, west Banda Aceh, during the 2004 Indian Ocean tsunami: understanding tsunami deposits using a forward modeling method, Nat. Hazards, 64, 1549-1574, 2012.

Masinha, L. and Smylie, D. E.: The displacement fields of inclined fault, B. Seismol. Soc. Am., 61, 1433-1440, 1971.

Matsutomi, H. and Okamoto, K.: Inundation flow velocity of tsunami load, Island Arc 19, 443-457, 2010.

Mori, N., Mai, P. M., Goda, K., and Yasuda, T.: Tsunami inundation variability from stochastic rupture scenarios: Application to multiple inversions of the 2011 Tohoku, Japan earthquake, Coast. Eng., 127, 88-105, 2017.

Nandasena, N. A. K., Sasaki, Y., and Tanaka, N.: Modeling field observations of the 2011 Great East Japan tsunami: Efficacy of artificial and natural structures on tsunami mitigation, Coast. Eng., 67, 1-13, 2012.

Nateghi, R., Bricker, J. D., Guikema, S. D., and Bessho, A.: Statistical Analysis of the Effectiveness of Seawalls and Coastal Forests in Mitigation Tsunami Impacts in Iwate and Miyagi Prefectures, PLOS ONE, 11, e0158375, https://doi.org/10.1371/journal.pone.0158375, 2016

NOAA: Global Historical Tsunami Database, National Geophysical Data Center/World Data Service (NGDC/WDS), National Geophysical Data Center, NOAA, https://doi.org/10.7289/v5pn93h7, 2018.

Ohta, H., Iai, S., Nishida, Y., Morioka, S., and Iizuka, A.: Tsunami Induced by 2011 Tohoku-Pacific Ocean Earthquake and a Possible Renewal Plan, in: Geotechnical Predictions and Practice in Dealing with Geohazards, edited by: Chu, J., Wardani, S., and Iizuka A., Geotechnical, Geological and Earthquake Engineering, vol 25, Springer Science+Business Media Dordrecht, 2013.

Okada, M.: Surface deformation due to shear and tensile faults in a half-space, B. Seismol. Soc. Am., 75, 1135-1154, 1985.

Ozer, C. and Yalciner, A. C.: Sensitivity Study of Hydrodynamic Parameters During Numerical Simulations of Tsunami Inundation, Pure Appl. Geophys., 168, 2083-2095, 2011.

Ozer, S. C., Yalciner, A. C., Zaytsev, A., Suppasri A., and Imamura, F.: Investigation of Hydrodynamic Parameters and the Effects of Breakwaters During the 2011 Great East Japan Tsunami in Kamaishi Bay, Pure Appl. Geophys., 172, 3473-3491, 2015. 
Pakoksung, K., Suppasri, A., and Imamura, F.: Systematic Evaluation of Different Infrastructure system for Tsunami Defense in Sendai City, Geoscience, 8, 173, https://doi.org/10.3390/geosciences8050173, 2018.

Samarasekara, R. S. M., Sasaki, J., Esteban, M., and Matsuda, H.: Assessment of the co-benefits of structures in coastal areas for tsunami mitigation and improving community resilience in Sri Lanka, Int. J. Disast. Risk Re., 23, 80-92, 2017.

Sengara, I. W., Latief, H., and Kusuma, S. B.: Probabilistic Seismic and Tsunami Hazard Analysis for Design Criteria and Disaster Mitigation in Rehabilitation and Reconstruction of a Coastal area in City of Banda Aceh, in: Geotechnical Engineering for Disaster Mitigation and Rehabilitation, edited by: Liu, H., Deng, A., and Chu, J., Springer, Berlin, Heidelberg, 2008.

Strusińska-Correia, A., Husrin, S., and Oumeraci, H.: Tsunami damping by mangrove forest: a laboratory study using parameterized trees, Nat. Hazards Earth Syst. Sci., 13, 483-503, https://doi.org/10.5194/nhess-13-483-2013, 2013.

Strusińska-Correia, A.: Tsunami mitigation in Japan after the 2011 Tohoku tsunami, Int. J. Disast. Risk Re., 22, 397-411, https://doi.org/10.1016/j.ijdrr.2017.02.001, 2017.

Sugawara, D., Imamura, F., Goto, K., Matsumoto, H., and Minoura, K.: The 2011 Tohoku-oki earthquake tsunami: Similarities and differences between the 869 Jogan tsunami on the Sendai Plain, Pure Appl. Geophys., 170, https://doi.org/10.1007/s00024-0120460-1, 2012.

Sugimoto, M., Iemura, H., and Shaw, R.: Tsunami height poles and disaster awareness-Memory, education and awareness of disaster on the reconstruction for resilient city in Banda Aceh, Indonesia, Disaster Prev. Manag., 19, 527-540, 2010.

Suppasri, A., Imamura, F., and Koshimura, S.: Effect of the rupture velocity of fault motion, ocean current and initial sea level on the transoceanic propagation of tsunami, Coast. Eng. J., 52, 107132, 2010.

Suppasri, A., Koshimura, S., and Imamura, F.: Developing tsunami fragility curves based on the satellite remote sensing and the numerical modeling of the 2004 Indian Ocean tsunami in Thailand, Nat. Hazards Earth Syst. Sci., 11, 173-189, https://doi.org/10.5194/nhess-11-173-2011, 2011.

Suppasri, A., Futami, T., Tabuchi, S., and Imamura, F.: Mapping of historical tsunamis in the Indian and Southwest Pacific Oceans, Int. J. Disast. Risk Re., 1, 62-71, 2012a.

Suppasri, A., Imamura, F., and Koshimura, S.: Tsunami hazard and casualty estimation in a coastal area that neighbors the Indian Ocean and South China Sea, Journal of Earthquake and Tsunami, 6, 1250010, https://doi.org/10.1142/S1793431112500108, $2012 b$

Suppasri, A., Latcharote, P., Bricker, J. D., Leelawat, N., Hayashi, A., Yamashita, K., Makinoshima, F., Roeber, V., and Imamura, F.: Improvement of tsunami countermeasures based on lessons from the 2011 great east japan earthquake and tsunami - Situation after five years, Coast. Eng. J., 58, 1640011, https://doi.org/10.1142/S0578563416400118, 2016.
Syamsidik, Iskandar, A., and Rasyif, T. M.: Progress of Coastal Line Rehabilitation After the Indian Ocean Tsunami Around Banda Aceh Coasts, in: Recovery from the Indian Ocean Tsunami, edited by: Shaw, R., Disaster Risk Reduction (Methods, Approaches and Practices), Springer, Tokyo, 2015.

Syamsidik, Oktari, R. S., Munadi, K., Arief, S., and Fajri, I. Z.: Changes in coastal land use and the reasons for selecting places to live in Banda Aceh 10 years after the 2004 Indian Ocean tsunami, Nat. Hazards, 88, 1503-1521, 2017.

Takagi, H. and Bricker, J. D.: Assessment of the effectiveness of general breakwaters in reducing tsunami inundation in ishinomaki, Coast. Eng. J., 56, 1450018, https://doi.org/10.1142/S0578563414500181, 2014.

Takeuchi, H., Murashima, Y., Imamura, F., Shuto, N., and Yoshida, K.: Verification of tsunami run-up height records of Meiji Sanriku Tsunami and Showa Sanriku Tsunami on the coast of Iwate Prefecture using numerical simulation, Hist. Earthq., 20, 155163, 2005.

Tanaka, N., Yasuda, S., Iimura, K., and Yagisawa, J.: Combined effects of coastal forest and sea embankment on reducing the washout region of houses in the Great East Japan tsunami, J. Hydro-Environ. Res., 8, 270-280, 2014.

Tokida, K. and Tanimoto, R.: Lessons for countermeasures using earth structures against tsunami obtaine $d$ in the 2011 Off the Pacific Coast of Tohoku Earthquake, Soils Found., 54, 523-543, 2014.

Tsuji, Y., Tanioka, Y., Matsutomi, H., Nishimura, Y., Kamataki, T., Murakami, Y., Sakakiyama, T., Moore, A., Gelfenbaum, G., Nugroho, S., Waluyo, B., Sukanta, I., Triyono, R., and Namegaya, Y.: Damage and height distribution of Sumatra earthquake of December 26, 2004, in Banda Aceh city and its environs, Journal of Disaster Research, 1, 103-115, 2006.

Wang, X.: User manual for Cornell multi-grid coupled tsunami model-COMCOT V1.7, available at: http://citeseerx.ist.psu.edu/ viewdoc/download?doi=10.1.1.512.84\&rep=rep1\&type=pdf (last access: 12 January 2017), 2009.

Wells, D. L. and Coppersmith, K. J.: New empirical relationships among magnitude, rupture length, rupture width, rupture area, and surface displacement, B. Seismol. Soc. Am., 84, 974-1002, 1994.

Yamamoto, Y., Takanashi, H., Hettiarachi, S., and Samarawickrama, S.: Verification of the destruction mechanism of structures in Sri Lanka and Thailand due to the Indian Ocean tsunami, Coast. Eng. J., 48, 117-145, 2006.

Yanagisawa, H., Koshimura, S., Goto, K., Miyagi, T., Imamura, F., Ruangrassamee, A., and Tanavud, C.: The reduction effects of mangrove forest on tsunami based on field surveys at Pakarang Cape, Thailand and numerical analysis, Estuar. Coast. Shelf S., 81, 27-37, 2009. 